\title{
Oxidative stress and antioxidant defence markers in muscle tissue of rainbow trout (Oncorhynchus mykiss) after vaccination against Yersinia ruckeri
}

\author{
Halyna Tkachenko ${ }^{1}$, Joanna Grudniewska ${ }^{2}$, \\ Agnieszka Pękala ${ }^{3}$, Elżbieta Terech-Majewska ${ }^{4}$ \\ ${ }^{1}$ Department of Zoology and Animal Physiology, \\ Institute of Biology and Environmental Protection, Pomeranian University in Slupsk, 76-200 Słupsk, Poland \\ ${ }^{2}$ Department of Salmonid Research, \\ S. Sakowicz Inland Fisheries Institute, 83-330 Zukowo, Poland \\ ${ }^{3}$ Department of Fish Diseases, \\ National Veterinary Research Institute, 24-100 Pulawy, Poland \\ ${ }^{4}$ Department of Epizootiology, \\ University of Warmia and Mazury in Olsztyn, 10-718 Olsztyn, Poland \\ tkachenko@apsl.edu.pl
}

Received: July 17, 2015

Accepted: February 3, 2016

\begin{abstract}
Introduction: The goal of this study was to assess the influence of vaccination against enteric redmouth disease on oxidative stress biomarkers and antioxidant defence in the muscle tissue of rainbow trout (Oncorhynchus mykiss Walbaum) vaccinated against Yersinia ruckeri in the first and second month after immunisation. Material and Methods: Healthy fish were vaccinated orally with inactivated whole cells of a virulent strain of $Y$. ruckeri. One and two months after immunisation the muscle samples were collected. Results: No significant difference was noted in lipid peroxidation level in either the first or second month after vaccination, while aldehydic and ketonic derivatives of oxidatively modified proteins (OMB) in the vaccinated group were significantly lower in the second month compared to those in the first month after vaccination $(\mathrm{P}<0.05)$. The content of ketonic derivatives of OMB in muscles in the first month after immunisation was higher compared to untreated control. All these culminated in a depletion of glutathione peroxidase (GPx) activity and low level of total antioxidant capacity (TAC). Conclusion: Correlations between catalase activity and lipid peroxidation and TAC confirmed the pivotal role of catalase in antioxidant defence during immunisation. From a broader perspective, it is suggested that immunisation of fish with Yersinia vaccine is associated with induced free radical formation and oxidative stress. Free radicals would therefore be at least partially responsible for the induction of both humoral and cellular elements of the immunity and increased protective immunity against $Y$. ruckeri infection.
\end{abstract}

Keywords: rainbow trout, Oncorhynchus mykiss, Yersinia ruckeri, immunisation, oxidative stress, muscles.

\section{Introduction}

Yersinia ruckeri is the causative agent of yersiniosis, or enteric redmouth disease (ERM), leading to significant economic losses in salmonid aquaculture worldwide. Infection may result in asepticaemic condition with haemorrhages on body surface and in internal organs (29). The specific pathogenic mechanisms of this bacterium have remained elusive until recently, when the results obtained with traditional microbiology have been complemented with those provided by molecular biology (8). Very little information is available on the pathogenesis hampering the development of preventive measures to efficiently combat this bacterial agent (29). The data obtained by using novel techniques have started to shed light on the virulence of this pathogen. Iron acquisition by the siderophore ruckerbactin, proteolytic, and haemolytic activities, and resistance to immune mechanisms, were proved to be involved in the virulence of this bacterium (8).

Numerous outbreaks of ERM caused by $Y$. ruckeri in rainbow trout farms are currently being recorded despite established vaccination procedures against the 
disease. This could indicate that the currently used application of single immersion vaccination does not provide full protection (4).

Y. ruckeri bacterin was the first commercially produced fish vaccine, and the formalin-killed wholecell product continues to be highly effective whether administered by immersion, spray, injection, or oral routes. Serovar 1 "Hagerman" strains are the basis for most commercial bacterins, and serovar 2 is not included, despite epizootics in chinook salmon and brook trout. Vaccination studies have reported different degrees of cross-protection between serogroups of $Y$. ruckeri, but the basis for the cross-protection is not clear. Lipopolysaccharide (LPS) of serovar 1 Y. ruckeri elicits negligible or weak antibody responses in fish and low cell-proliferation memory responses compared with serovar 2 strains (28). Y. ruckeri bacterin can be administered by intraperitoneal (i.p.) injection, immersion, and oral administration (14). The obtained protective immunity is superior with i.p. injection followed by immersion, and oral administration (14). Antibodies in rainbow trout only in few cases are associated with protection following immersion vaccination (23).

The oxidative stress markers are important indicators of the physiological state of fish immunised by vaccine against $Y$. ruckeri. Among different markers of oxidative stress, 2-thiobarbituric acid reactive substances (TBARS), content of oxidative protein damage, and natural antioxidants: metalloenzymes, superoxide dismutase (SOD), catalase (CAT), and selenium dependent glutathione peroxidase (GPx), are currently considered to be the most important (24). Malondialdehyde (MDA) is a three-carbon compound formed from peroxidised polyunsaturated fatty acids, mainly arachidonic acid. It is one of the end products of membrane lipid peroxidation. Since MDA content increases in various diseases with excess of reactive oxygen species (ROS), many relationships with free radical damage were observed (24). CAT and SOD are the major defences against ROS. SOD converts superoxide anions into $\mathrm{H}_{2} \mathrm{O}_{2}$, and CAT converts $\mathrm{H}_{2} \mathrm{O}_{2}$ to molecular oxygen and water (12). SOD exists in two forms: $\mathrm{Cu}, \mathrm{Zn}-\mathrm{SOD}$, primarily present in the cytoplasm, and Mn-SOD, present primarily in the mitochondria. $\mathrm{Cu}, \mathrm{Zn}-\mathrm{SOD}$ is an intracellular enzyme present in all oxygen-metabolising cells, which dismutates the extremely toxic superoxide radical into potentially less toxic hydrogen peroxide. GPx, an intracellular enzyme, belongs to a group of several proteins in cells that can metabolise $\mathrm{H}_{2} \mathrm{O}_{2}$ and lipid hydroperoxides (24).

Therefore, exploring the effects of vaccination against $Y$. ruckeri on oxidative stress biomarkers in different tissues and monitoring the health condition of trout in general would be valuable. In the present study, we determined the influence of vaccination against yersiniosis on oxidative stress biomarkers and antioxidant defence in the muscle tissue of the rainbow trout (Oncorhynchus mykiss Walbaum) vaccinated against $Y$. ruckeri in the first and second month after immunisation. The following parameters were evaluated in the muscles of rainbow trout immunised with $Y$. ruckeri vaccine: oxidative stress biomarkers: 2-thiobarbituric acid reactive substances (TBARS), aldehydic and ketonic derivatives of oxidatively modified proteins (OMB), as well as activities of the antioxidant enzymes (superoxide dismutase, catalase, glutathione reductase, glutathione peroxidase, and total antioxidant capacity).

\section{Material and Methods}

Experimental animals. Clinically healthy rainbow trout with a mean body mass of $107.9 \pm 3.1 \mathrm{~g}$ were used in the experiments. The experiments were performed in water at $14.5 \pm 0.5^{\circ} \mathrm{C}$ and $\mathrm{pH} 7.2-7.4$. The dissolved oxygen level was about $9 \mathrm{ppm}$ with additional oxygen supply, with a water flow of $25 \mathrm{~L} / \mathrm{min}$, and a photoperiod of $12 \mathrm{~h}$ per day. The same experimental conditions were used during the whole research. The water parameters were maintained under constant surveillance. The fish were held in square tanks (150 fish per tank) and fed commercial pelleted diet.

Experimental design. The fish were divided into two groups: untreated control and immunised against ERM. The vaccine against ERM (Department of Fish Diseases, National Veterinary Research Institute, Pulawy, Poland) contained three inactivated Y. ruckeri strains originating from rainbow trout cultured at different farms, in which fish were exhibiting clinical signs of ERM. The bacteria isolates belonged to $\mathrm{O} 1$ serotype and showed some differences in their biochemical properties. Concentrated vaccine was incorporated into fish feed and was administered three times every other day. Fifteen rainbow trout from each group were euthanised 30 and $60 \mathrm{~d}$ after the immunisation, and then muscle samples were collected.

Laboratory analyses. The muscle samples were homogenised in ice-cold buffer $(100 \mathrm{mM}$ Tris- $\mathrm{HCl}$, $\mathrm{pH}$ 7.2) using a glass homogeniser immersed in ice water bath. Homogenates were centrifuged at $3000 \mathrm{~g}$ for $15 \mathrm{~min}$ at $4^{\circ} \mathrm{C}$. After centrifugation, the supernatant was collected and frozen at $-20^{\circ} \mathrm{C}$ until analysis. Protein contents were determined with the method described by Bradford (3) with bovine serum albumin as a standard. Absorbance was recorded at $595 \mathrm{~nm}$. All enzymatic assays were carried out at $22 \pm 0.5^{\circ} \mathrm{C}$ using a Specol 11 spectrophotometer (Carl Zeiss Jena, Germany) in duplicate. The enzymatic reactions were started by adding the tissue supernatant.

Determination of 2-thiobarbituric acid reactive substances (TBARS). The level of lipid peroxidation was determined by quantifying the concentration of TBARS with the Kamyshnikov method for determining the MDA concentration (15). Briefly, $2.1 \mathrm{~mL}$ of sample homogenate (in tris- $\mathrm{HCl}$ buffer, $100 \mathrm{mM}, \mathrm{pH}$ 7.2) was added to $1 \mathrm{~mL}$ of $20 \%$ of 2 -thiobarbituric acid (TCA), 
and $1 \mathrm{~mL}$ of $0.8 \%$ of trichloroacetic acid (TBA). The mixture was heated in a boiling water bath for $10 \mathrm{~min}$. After cooling, the mixture was centrifuged at $3000 \mathrm{~g}$ for $10 \mathrm{~min}$. The absorbance of the supernatant was measured at $540 \mathrm{~nm}$. The concentration of MDA $(\mathrm{nmol} / 1 \mathrm{mg}$ of protein) was calculated using $1.5610^{5} \mathrm{mM}^{-1} \mathrm{~cm}^{-1}$ as the extinction coefficient.

Measurement of carbonyl groups of oxidatively modified protein. The rate of protein oxidative destruction was estimated from the reaction of the resultant carbonyl derivatives of amino acid reaction with 2,4-dinitrophenylhydrazine (DNPH) as described by Levine et al. (20), modified by Dubinina et al. (6). DNPH was used for determining carbonyl content in soluble and insoluble proteins. Briefly, $1 \mathrm{~mL}$ of $0.1 \mathrm{M}$ DNPH (dissolved in $2 \mathrm{M} \mathrm{HCl}$ ) was added to $0.1 \mathrm{~mL}$ of the sample after denaturation of proteins by $20 \%$ TCA. After addition of the DNPH solution (or $2 \mathrm{M} \mathrm{HCl}$ to the blanks), the tubes were incubated for $1 \mathrm{~h}$ at $37^{\circ} \mathrm{C}$. The tubes were spun in a centrifuge for $20 \mathrm{~min}$ at $3000 \mathrm{~g}$. After centrifugation, the supernatant was decanted and $1 \mathrm{~mL}$ of ethanol-ethylacetate solution was added to each tube. After mechanical disruption of the pellet, the tubes were allowed to stand for $10 \mathrm{~min}$ and then spun again (20 min at $3000 \mathrm{~g}$ ). The supernatant was decanted, and the pellet was washed thrice with ethanol-ethylacetate solution. After the final wash, the protein was solubilised in $2.5 \mathrm{~mL}$ of $8 \mathrm{M}$ urea solution. To speed up the solubilisation process, the samples were incubated at $90^{\circ} \mathrm{C}$ in a water bath for 10 to $15 \mathrm{~min}$. The final solution was centrifuged to remove any insoluble material. The carbonyl content was calculated from the absorbance measurement at $370 \mathrm{~nm}$ and $430 \mathrm{~nm}$, and an absorption coefficient of $22000 \mathrm{M}^{-1} \mathrm{~cm}^{-1}$. Carbonyl groups were determined spectrophotometrically from the difference in absorbance at $370 \mathrm{~nm}$ (aldehydic derivatives, $\mathrm{OMP}_{370}$ ) and $430 \mathrm{~nm}$ (ketonic derivatives, $\mathrm{OMP}_{430}$ ).

Assay of superoxide dismutase activity. Superoxide dismutase (SOD, E.C. 1.15.1.1) activity was assessed by its ability to dismutate superoxide produced during quercetin auto-oxidation in an alkaline medium ( $\mathrm{pH}$ 10.0) using the method described by Kostiuk et al. (18). Briefly, $1.0 \mathrm{~mL}$ of $\mathrm{C}$ reagent was mixed with $0.1 \mathrm{~mL}$ of sample (dilution in water, 1:1000). $\mathrm{C}$ reagent was made ex tempore (mixture of equal

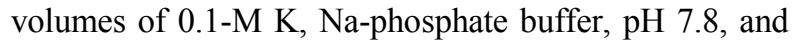
0.08-M EDTA solution); $\mathrm{pH}$ of $\mathrm{C}$ reagent was adjusted to 10.0 by adding tetramethylenediamine. Distilled water $(0.1 \mathrm{~mL})$ was added to blank vials instead of blood sample. The total volume of all samples was brought up to $2.4 \mathrm{~mL}$ using distilled water. The reaction was initiated by adding $0.1 \mathrm{~mL}$ of quercetin $(1.4 \mathrm{mM}$ dissolved in dimethyl sulfoxide). Absorbance at $406 \mathrm{~nm}$ was measured immediately and $20 \mathrm{~min}$ after addition of quercetin solution. Activity was expressed in units of $\mathrm{SOD} / \mathrm{mg}$ of tissue protein.

Measurement of catalase activity. Catalase (CAT, E.C. 1.11.1.6) activity was determined by measuring the decrease of $\mathrm{H}_{2} \mathrm{O}_{2}$ in the reaction mixture using a spectrophotometer at the wavelength of $410 \mathrm{~nm}$ using the method described by Koroliuk et al. (17). The reaction was initiated by adding $0.1 \mathrm{~mL}$ of the sample into the incubation medium $\left(2 \mathrm{~mL}\right.$ of $0.03 \% \mathrm{H}_{2} \mathrm{O}_{2}$ solution) and to $1.0 \mathrm{~mL}$ of $4 \%$ ammonium molybdate dissolved in $12.5 \mathrm{mM} \mathrm{H}_{2} \mathrm{SO}_{4}$ solution (blank sample). The duration of reaction was $10 \mathrm{~min}$ at room temperature. The reaction was terminated by adding $1.0 \mathrm{~mL}$ of $4 \%$ ammonium molybdate dissolved in $12.5 \mathrm{mM} \mathrm{H}_{2} \mathrm{SO}_{4}$ solution to incubation medium and $1 \mathrm{~mL}$ of $125 \mathrm{mM} \mathrm{H}_{2} \mathrm{SO}_{4}$ to all samples. The samples were centrifuged at $3000 \mathrm{~g}$ for $5 \mathrm{~min}$. The absorbance of the obtained solution was measured at $410 \mathrm{~nm}$ and compared with that of the blank sample. One unit of CAT activity was defined as the amount of enzyme required for decomposition of $1 \mu \mathrm{mol} \mathrm{H}_{2} \mathrm{O}_{2} / \mathrm{min} / \mathrm{mg}$ of protein.

Measurement of glutathione reductase activity. Glutathione reductase (GR, EC 1.6.4.2) activity in the blood was measured according to the method described by Glatzle et al. (13) with some modifications. The enzymatic activity was assayed spectrophotometrically by measuring $\mathrm{NADPH}_{2}$ consumption. In the presence of GSSG and $\mathrm{NADPH}_{2}$, GR reduces GSSG and oxidises $\mathrm{NADPH}_{2}$, resulting in a decrease in the absorbance at $340 \mathrm{~nm}$. The enzyme assay mixture contained $2.4 \mathrm{~mL}$ of $67 \mathrm{mM}$ sodium phosphate buffer $(\mathrm{pH} 6.6), 0.2 \mathrm{~mL}$ of $7.5 \mathrm{mM}$ oxidised glutathione, and $0.1 \mathrm{~mL}$ of sample. The rate of $\mathrm{NADPH}_{2}$ oxidation was measured spectrophotometrically at $340 \mathrm{~nm}$. Quantification was performed based on a molar extinction coefficient of $6.22 \mathrm{mM}^{-1} \cdot \mathrm{cm}^{-1}$ of $\mathrm{NADPH}_{2}$. The GR activity was expressed as $\mu \mathrm{mol}$ of $\mathrm{NADPH}_{2} / \mathrm{min} / \mathrm{mg}$ of protein.

Assay of glutathione peroxidase activity. Glutathione peroxidase (GPx, EC 1.11.1.9) activity was determined by detecting the nonenzymatic utilisation of GSH (the reacting substrate) at an absorbance of $412 \mathrm{~nm}$ after incubation with 5,5-dithiobis-2-nitrobenzoic acid (DTNB) according to the method of Moin (22). The assay mixture contained $0.8 \mathrm{~mL}$ of $0.1 \mathrm{M}$ tris- $\mathrm{HCl}$ buffer

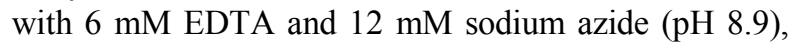
$0.1 \mathrm{~mL}$ of $4.8 \mathrm{mM} \mathrm{GSH}, 0.2 \mathrm{~mL}$ of sample, $1 \mathrm{~mL}$ of $20 \mathrm{mM}$ t-butyl hydroperoxide, and $0.1 \mathrm{~mL}$ of $0.01 \mathrm{M}$ DTNB. The rate of GSH reduction was measured spectrophotometrically at $412 \mathrm{~nm}$. Glutathione peroxidase activity was expressed as $\mu \mathrm{mol} \mathrm{GSH} / \mathrm{min} / \mathrm{mg}$ of protein.

Measurement of total antioxidant capacity (TAC). The TAC level in the plasma was estimated by measuring the TBARS level after Tween 80 oxidation. This level was determined spectrophotometrically at $532 \mathrm{~nm}$ (10). Plasma inhibits the $\mathrm{Fe}^{2+} /$ ascorbate-induced oxidation of Tween 80 , resulting in a decrease in the TBARS level. Briefly, $0.1 \mathrm{~mL}$ of sample was added to $2 \mathrm{~mL}$ of $1 \%$ Tween 80 reagent, $0.2 \mathrm{~mL}$ of $1 \mathrm{mM} \mathrm{FeSO}_{4}$, and $0.2 \mathrm{~mL}$ of $10 \mathrm{mM}$ ascorbic acid. In the blank assay, $0.1 \mathrm{~mL}$ of distilled water was used instead of the sample. The mixture was heated in boiling water bath for $48 \mathrm{~h}$ at $37^{\circ} \mathrm{C}$. After cooling, $1 \mathrm{~mL}$ of $20 \%$ TCA was added. 
The mixture was centrifuged at $3000 \mathrm{~g}$ for $10 \mathrm{~min}$. After centrifugation, $2 \mathrm{~mL}$ of supernatant and $2 \mathrm{~mL}$ of $0.25 \%$ TBA reagent were mixed. The mixture was heated in a water bath at $95^{\circ} \mathrm{C}$ for $15 \mathrm{~min}$. The absorbance of the obtained solution was measured at $532 \mathrm{~nm}$. The absorbance of the blank was defined as $100 \%$. The level of TAC in the sample (\%) was calculated with respect to the absorbance of the blank sample.

Statistical analysis. Data were presented as the mean \pm S.E.M. and were checked for assumptions of normality using the Kolmogorov-Smirnov one-sample test and Lilliefors tests $(\mathrm{P}>0.05)$. Significance of differences in the lipid peroxidation level, level of carbonyl derivatives of amino acid reaction, and antioxidant enzyme activities were examined using Mann-Whitney $U$ test according to Zar (32). In addition, the relationships between oxidative stress biomarkers of all individuals were evaluated using Spearman's correlation analysis. All statistical analysis was performed by STATISTICA 10.0 software (StatSoft, Poland).

\section{Results}

The lipid peroxidation (TBARS level) in the muscle tissue of trout vaccinated against $Y$. ruckeri did not differ significantly from that in controls in the first and second month after immunisation (Fig. 1).

Aldehydic and ketonic derivatives of oxidatively modified proteins in the muscle tissue of control group and the group vaccinated against $Y$. ruckeri were significantly reduced (by $30 \%, \mathrm{P}=0.049$ and by $54.4 \%$, $\mathrm{P}=0.000$ respectively) in the second month after immunisation compared to those after the first month (Fig. 2). Vaccination caused a significant decrease (by $44 \%, \mathrm{P}=0.006$ ) in the level of ketonic derivatives in the muscle tissue two months after vaccination compared to the values after the first month. Higher aldehydic and ketonic derivatives of protein damage were found in fish in the first month after immunisation $(37.72 \pm 4.27$ and $27 \pm 3.01 \mathrm{nmol} / \mathrm{mg}$ of protein respectively) (Fig. 2). Ketonic derivatives of $\mathrm{OMB}$ content in the muscle of vaccinated fish was higher by $45 \%(\mathrm{P}=0.037)$ in the first month after immunisation compared to controls (Fig. 2B).

The antioxidant defence markers in the muscle tissue in response to anti-Yersinia vaccine treatment are presented in Table 1. SOD activity in muscle of vaccinated fish in the first month after immunisation was higher by $5.3 \%(\mathrm{P}=0.036)$ compared to controls. Muscle CAT activity was significantly higher in control group in the second month (by $118.5 \%, \mathrm{P}=0.013$ ) compared to control group in the first month, as well as in vaccinated group in the second month (by $71.6 \%$, $\mathrm{P}=0.005)$ compared to vaccinated group in the first month. GR activity was significantly higher in control group in the second month (by $8.4 \%, \mathrm{P}=0.041$ ) compared to control group in the first month. Two months after immunisation, GR activity was lower by $45.6 \%(\mathrm{P}=0.017)$ compared to control group. GPx activity in the muscle was also significantly inhibited in both control and vaccinated groups in the second month (by $82.5 \%$ and by $83 \%, \mathrm{P}=0.000$ respectively) compared to the values in the first month after immunisation. TAC, which is another marker used for indirect determination of the levels of oxidative stress in tissue (2), was significantly increased in the muscles of vaccinated group compared to those in the controls in the second month after immunisation (by $77.9 \%, \mathrm{P}=0.013$ ) (Table 1).

Correlations between oxidative stress and antioxidant defence markers in the muscle tissue of the trout vaccinated against $Y$. ruckeri in the first and second month after immunisation are presented in Table 2 .

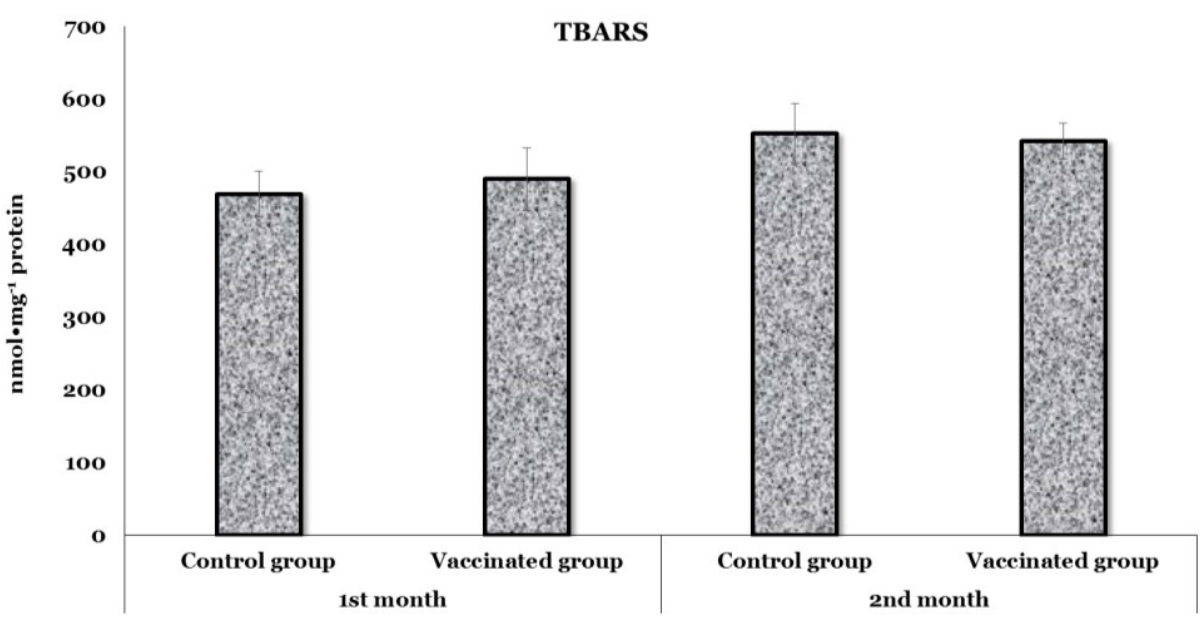

Fig. 1. The lipid peroxidation (TBARS level) in the muscle tissue of the trout vaccinated against Y. ruckeri in the first and second month after immunisation. Data are presented as mean \pm S.E.M. $(n=15)$ 

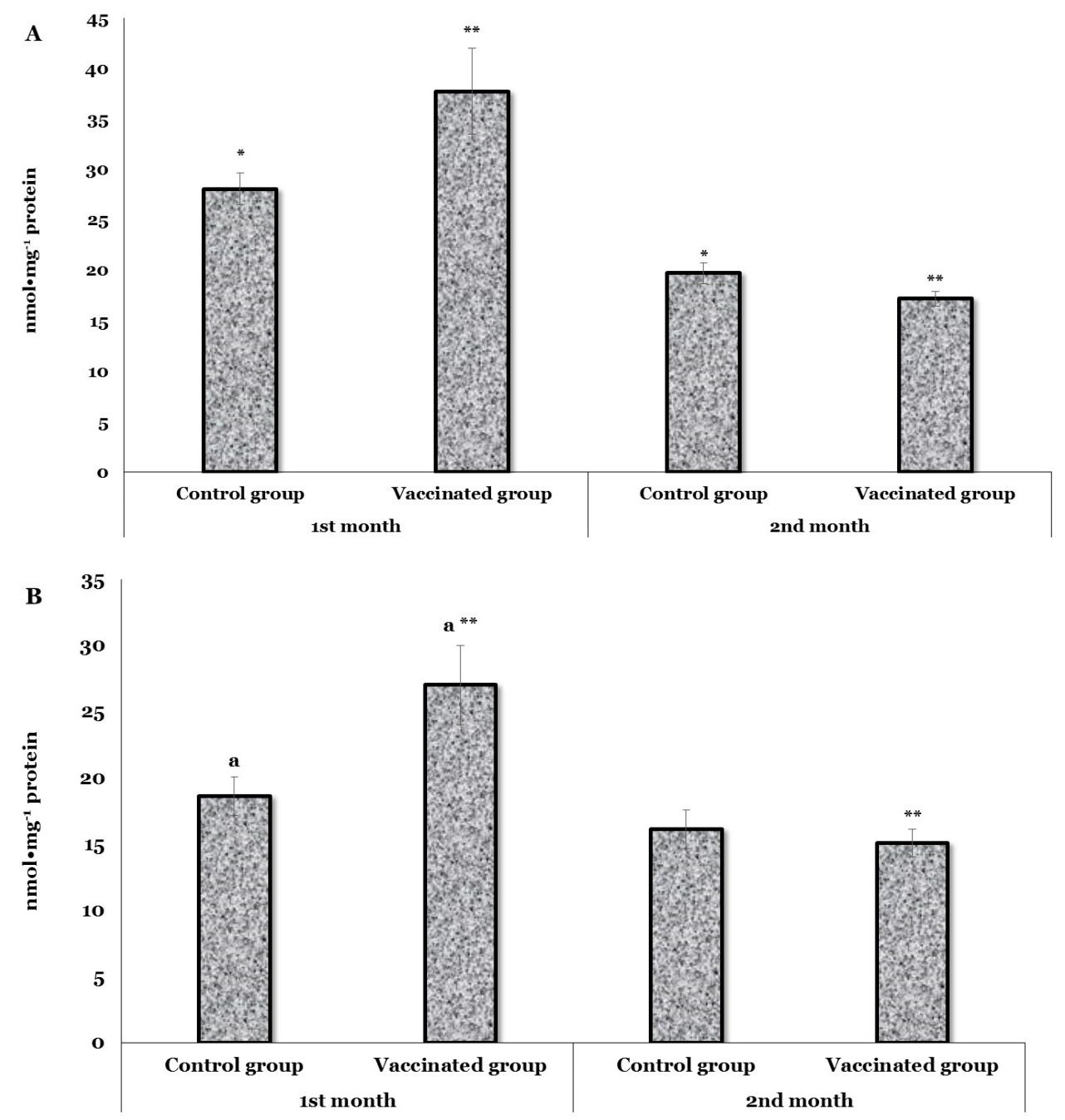

Fig. 2. Aldehydic (A) and ketonic derivatives (B) of oxidatively modified proteins in the muscle tissue of the trout vaccinated against $Y$. ruckeri in the first and second month after immunisation. Data are presented as mean \pm S.E.M. $(\mathrm{n}=15)$

* $-\mathrm{P}<0.05$ when compared to control group values in the first and second month after immunisation;

** $-\mathrm{P}<0.05$ when the values for vaccinated group were compared in the first and second month after immunisation;

${ }^{\mathrm{a}}-\mathrm{P}<0.05$ when the values for control group and vaccinated group were compared in the first month after immunisation

Table 1. Antioxidant defence markers in the muscle tissue of trout vaccinated against $Y$. ruckeri in the first and second month after immunisation

\begin{tabular}{|c|c|c|c|c|}
\hline \multirow{2}{*}{ Antioxidant enzymes } & \multicolumn{2}{|c|}{ First month } & \multicolumn{2}{|c|}{ Second month } \\
\hline & Control group & Vaccinated group & Control group & Vaccinated group \\
\hline $\mathrm{SOD}, \mathrm{U} \cdot \mathrm{mg}^{-1}$ protein & $339.16 \pm 5.54^{\mathrm{a}}$ & $357.26 \pm 5.20^{\mathrm{a}}$ & $360.19 \pm 28.72$ & $327.89 \pm 19.21$ \\
\hline $\begin{array}{l}\mathrm{CAT}, \mu \mathrm{mol} \cdot \mathrm{min}^{-1} \cdot \mathrm{mg}^{-1} \\
\text { protein }\end{array}$ & $5.20 \pm 0.90^{*}$ & $6.30 \pm 0.79 * *$ & $11.36 \pm 2.24^{*}$ & $10.81 \pm 1.42 * *$ \\
\hline $\mathrm{GR}, \mu \mathrm{mol} \cdot \mathrm{min}^{-1} \cdot \mathrm{mg}^{-1}$ protein & $6.82 \pm 2.86^{*}$ & $5.57 \pm 1.22$ & $7.39 \pm 1.24 * \mathrm{~b}$ & $4.02 \pm 0.94^{\mathrm{b}}$ \\
\hline $\mathrm{GPx}, \mu \mathrm{mol} \cdot \mathrm{min}^{-1} \cdot \mathrm{mg}^{-1}$ protein & $233.69 \pm 25.64^{*}$ & $223.09 \pm 34.96^{* *}$ & $40.90 \pm 6.78^{*}$ & $38.05 \pm 9.65^{* *}$ \\
\hline TAC, $\%$ & $12.01 \pm 1.54 *$ & $16.59 \pm 3.04$ & $6.19 \pm 1.54^{* \mathrm{~b}}$ & $11.01 \pm 1.53^{\mathrm{b}}$ \\
\hline
\end{tabular}

Data are presented as mean \pm S.E.M. $(\mathrm{n}=15)$

* $-\mathrm{P}<0.05$ when the values for control group were compared in the first and second month after immunisation;

** $-\mathrm{P}<0.05$ when the values for vaccinated group were compared in the first and second month after immunisation;

a $-\mathrm{P}<0.05$ when the values for control group and vaccinated group were compared in the first month after immunisation;

$\mathrm{b}-\mathrm{P}<0.05$ when the values for control group and vaccinated group were compared in the second month after immunisation 
Table 2. Correlations between oxidative stress and antioxidant defence markers in the muscle tissue of the trout vaccinated against $Y$. ruckeri in the first and second month after immunisation

\begin{tabular}{|c|c|c|}
\hline \multirow[t]{2}{*}{ Correlations } & Correlation coefficient, $r$ & Significance level, $\mathrm{p}$ \\
\hline & \multicolumn{2}{|c|}{ Control group, first month after immunisation } \\
\hline Aldehydic derivatives of oxidatively modified proteins-GPx & 0.543 & 0.037 \\
\hline \multirow[t]{2}{*}{ Ketonic derivatives of oxidatively modified proteins-GPx } & 0.525 & 0.044 \\
\hline & \multicolumn{2}{|c|}{ Vaccinated group, first month after immunisation } \\
\hline TBARS-CAT & 0.617 & 0.014 \\
\hline Aldehydic derivatives of oxidatively modified proteins-TAC & 0.664 & 0.007 \\
\hline Ketonic derivatives of oxidatively modified proteins-TAC & 0.612 & 0.015 \\
\hline \multirow[t]{2}{*}{ CAT-TAC } & 0.572 & 0.025 \\
\hline & \multicolumn{2}{|c|}{ Control group, second month after immunisation } \\
\hline Ketonic derivatives of oxidatively modified proteins-CAT & 0.521 & 0.046 \\
\hline \multirow[t]{2}{*}{ GPX-TAC } & -0.546 & 0.036 \\
\hline & \multicolumn{2}{|c|}{ Vaccinated group, second month after immunisation } \\
\hline CAT-GR & 0.579 & 0.024 \\
\hline GPx-TAC & -0.518 & 0.048 \\
\hline
\end{tabular}

\section{Discussion}

Vaccination of salmonids against $Y$. ruckeri has been conducted successfully for more than 30 years but the protective mechanisms in fish activated by this type of immunisation are still being debated. In the present study, we have demonstrated the induction of oxidative stress in the muscle tissue of rainbow trout after vaccination on the basis of the most widely used and accepted markers: TBARS as a marker of lipid peroxidation, aldehydic and ketonic derivatives of oxidatively modified proteins, antioxidant enzymes activity, and the total antioxidant capacity. TBARS, which is the final product of lipid peroxidation induced by free radicals, has been implicated as the most important cause of destruction and damage in cell membranes. This occurs because the polyunsaturated fatty acids of cell membranes are degraded by this process, with consequent rupture of membrane integrity. Membrane peroxidation may lead to changes in membrane fluidity and permeability, and may also increase protein degradation and rates of cell lysis $(2,11)$. Lipid peroxidation has been implicated in the aetiology of damage to subcellular membranes by inactivating cell constituents through oxidation or inducing oxidative stress by undergoing radical chain reaction (1). In this study our results clearly demonstrate that immunisation by antiYersinia vaccine does not alter the muscle tissue of rainbow trout. Oxidative stress parameters were examined in muscle homogenate, and lipid peroxidation, assessed on the basis of the amount of MDA, was non-significantly changed $(\mathrm{P}>0.05)$ in the muscle tissue of vaccine-treated fish (Fig. 1).

Because the generation of carbonyl derivatives occurs by many different mechanisms, the level of carbonyl groups in proteins is widely used as a marker of oxidative protein damage $(20,27)$. The present work has also shown that the aldehydic and ketonic derivatives of oxidatively modified proteins decreased significantly following vaccination against $Y$. ruckeri. Decreased levels of aldehydic and ketonic derivatives were found 8 weeks post-vaccination, which corresponds to the time required at $15^{\circ} \mathrm{C}$ to develop protective immunity against $Y$. ruckeri (25). Fig. 2 shows a significant $(\mathrm{P}<0.05)$ decline in the production of aldehydic and ketonic derivatives of oxidatively modified proteins in the muscle tissue of anti-Yersinia vaccinated fish in the second month compared to the values in the first month after immunisation, as well as vaccine-induced alteration in the function of some antioxidant enzyme markers.

Immunisation against $Y$. ruckeri resulted in a significant $(\mathrm{P}<0.05)$ decrease in glutathione peroxidase enzyme activity in the muscle tissue in the second month after immunisation. Our study also showed that there was a significant $(\mathrm{P}<0.05)$ increase in catalase activity with a decrease in glutathione peroxidase activity in the muscle tissue of controls in the second month compared to that in the first month after immunisation. In the first month after immunisation, anti-Yersinia vaccination resulted in an increase in the production of aldehydic and ketonic derivatives of oxidatively modified proteins, with elevated glutathione peroxidase activity. In the second month after immunisation, the vaccination resulted in a decrease in the levels of oxidatively modified proteins. All these culminated in a depletion of glutathione peroxidase activity and low levels of total antioxidant capacity (Table 1). Our results indicated that aldehydic and ketonic derivatives of oxidatively modified proteins are correlated with TAC $(\mathrm{r}=0.664$, $\mathrm{P}=0.007$ and $\mathrm{r}=0.612, \mathrm{P}=0.015$ respectively) in the muscle tissue of vaccinated fish one month after immunisation (Table 2). 
We assume that the reaction of the adaptive response of the immune system during vaccination against $Y$. ruckeri is enhanced by oxidative stress. Antioxidant defence of fish tissues confers a high degree of protection to the fish against vaccineinduced oxidative stress. Actually, when a microbe is recognised by phagocytes and engulfed, it triggers a process, called respiratory burst, in which phagocytes elevate their oxygen consumption. The NADPH-oxidase (NOX2) is pivotal to the respiratory burst through generation of ROS. It also actively participates in cellular activities, including neutrophil extracellular trap (NET) formation and inflammasome activation, and attaches itself to the phagosomal membrane during phagocytosis (31).

Fish are the most primitive gnathostomes (jawed vertebrates) possessing an adaptive immune system (25). The reaction of the adaptive response of the immune system is enhanced by oxidative stress (19) which is a process associated with the action of ROS and reactive metabolites in the organism (7). The results of Ryckaert et al. (26) showed that Y. ruckeri induced the production of reactive oxygen species, respiratory burst response, and macrophage viability. The authors clearly demonstrated the capacity of $Y$. ruckeri to survive in rainbow trout macrophages in vitro as well as in vivo, confirming its facultative intracellular nature. ROS play an irreplaceable role in phagocytosis as one of the significant microbicidal systems (16). Depending on the type of oxidants, intensity and time of redox imbalance, as well as on the type of cells, oxidative stress plays a role in the regulation of synthesis and activity of antioxidant defence (7).

Activation of immune factors by vaccination against $Y$. ruckeri plays a crucial role in respiratory burst through generation of ROS. Immunisation against $Y$. ruckeri reported here may play a significant role in vaccination-induced protein damage in muscle tissue of trout due to phagocyte respiratory burst. Many researchers confirmed the respiratory burst through generation of ROS as a result of activation of the immune system of fish vaccinated against Y. ruckeri. Chettri et al. (5) indicated that early life stages (yolk-sac larvae) merely up-regulate a few genes and a limited capacity of larvae to mount an immune response by gene regulation at the transcriptional level. It could be speculated that larvae may be covered by protective shield of different immune factors providing protection against broad range of pathogens. However, the increased susceptibility of older fry suggests that $Y$. ruckeri may utilise some of the immune elements to enter the naive fish. A high expression of cytokines (IL-1 $\beta$, TNF- $\alpha$, IL-22, IL- 8 , and IL-10), acute phase proteins (SAA, hepcidin, transferring, and precerebellin), complement factors $(\mathrm{C} 3, \mathrm{C} 5$, and factor $\mathrm{B})$, antimicrobial peptide (cathelicidin-2), and inducible nitric oxide synthase (iNOS) was found in infected fry when compared to the uninfected control. The upregulation of iNOS and IL-22 in the infected larvae implicates an important role of these molecules in immune response at early developmental stages. A dense covering of surfaces of gill filaments by $\operatorname{IgT}$ antibody in young fish suggests a role of this antibody as innate immune factor at early developmental stages (5).

Raida and Buchmann (25) also demonstrated that gene expression in fish vaccinated against $Y$. ruckeri was up-regulated with regard to pro-inflammatory cytokines IFN- $\gamma$, TNF- $\alpha$, and IL- 6 , and antiinflammatory cytokines IL-10 and TGF- $\beta$, cell receptors $\mathrm{TcR}, \mathrm{CD} 8 \alpha, \mathrm{CD} 4$, and $\mathrm{C} 5 \mathrm{aR}$, and the teleost specific immunoglobulin IgT. Humoral factors such as Ig and complement are less important in the protection induced by bath vaccination. Expression of cellular factors such as $\mathrm{CD} 8 \alpha$ was significantly increased in the protected trout and this suggests that cellular factors including cytotoxic T-cells could play a role in immunity against $Y$. ruckeri (25).

Wiens and Vallejo (30) reported temporal and quantitative changes in rainbow trout immune response parameters following a primary challenge with BT2 Y. ruckeri strain YRNC10. Fish were injection-challenged with ten-fold dilutions of viable bacteria and sampled on days $1,3,5$, and 7 postchallenge. TNF $\alpha 1$ and IL1- $\beta 1$ transcripts were increased by day 1 post-challenge. Y. ruckeri infection induced modest changes in INF $\gamma$ and Mx-1 gene transcript abundance at intermediate or high challenge doses and the expression patterns of both genes were positively correlated with pro-inflammatory gene and acute-phase gene transcription patterns. TNF superfamily 13b (BAFF) gene expression was significantly down-regulated in response to infection on days 3,5 , and 7 at the highest challenge doses. The spleen somatic index was significantly increased on days 3,5 , and 7 post-infection and positively correlated with spleen colony forming units and abundance of gene transcripts SAA, TNF $\alpha 1$, and IL1- $\beta 1$ (30). Therefore, immunisation is pivotal to the respiratory burst through generation of ROS in immunity against $Y$. ruckeri.

In summary, the findings described in the present study indicate that immunisation with anti-Yersinia vaccine does not alter oxidative stress markers compared to controls in the first and second month after immunisation. Correlative analysis between oxidative stress and antioxidant defence biomarkers confirm our conclusions (Table 2). Correlations between catalase activity and TBARS level $(\mathrm{r}=0.617$, $\mathrm{P}=0.014)$ and TAC $(\mathrm{r}=0.572, \mathrm{P}=0.025)$ in the muscle tissue of anti-Yersinia vaccinated animals in the first month confirm the pivotal role of catalase in antioxidant defence during immunisation (Table 2). Catalase converts $\mathrm{H}_{2} \mathrm{O}_{2}$ to $\mathrm{H}_{2} \mathrm{O}$. Moreover, among the ROS, $\mathrm{H}_{2} \mathrm{O}_{2}$ best of all fulfils the requirements of being a second messenger. Its enzymatic production 
and degradation, along with the requirements for the oxidation of thiols by $\mathrm{H}_{2} \mathrm{O}_{2}$, provide the specificity for time and place that are required in signalling. Among possible oxidation states of cysteine, formation of sulfenic acid derivatives or disulfides can be relevant as thiol redox switches in signalling (9). Makino et al. (21) have constructed a metabolic model describing the $\mathrm{H}_{2} \mathrm{O}_{2}$ elimination by cells. It comprises three compartments (medium, cytosol, and peroxisome) separated by cytoplasmic and peroxisomal membranes, and $\mathrm{H}_{2} \mathrm{O}_{2}$ moves across the membranes with different permeation rate constants. Catalase localises to peroxisomes, while glutathione peroxidase and GSH recycling system (glutathione reductase and oxidative pentose phosphate pathway) localise to cytosol (21). We have also shown that glutathione peroxidase enables to avoid the cellular lesions caused by anti-Yersinia vaccine. From a broader perspective, it is suggested that immunisation of fish by antiYersinia vaccine is associated with induced free radical formation and oxidative stress. ROS would therefore be at least partially responsible for the induction of both humoral and cellular elements of the immunity with increased protection against $Y$. ruckeri infection. Catalase and GPx are the major defence factors against oxidative stress induced by vaccination. Oxidative stress biomarkers, i.e. the content of oxidative protein damage, as well as antioxidant enzymes and total antioxidant capacity in the muscle tissue, may potentially be used as biomarkers in evaluating anti-Yersinia vaccine efficacy in rainbow trout.

Conflict of Interests Statement: The authors declare that there is no conflict of interests regarding the publication of this manuscript.

Financial Disclosure Statement: The manuscript was supported by Grant of the Pomeranian University in Slupsk for Young Scientists, Poland.

Animal Rights Statement: The experiment was conducted in accordance with local Ethical Committee laws and regulations as regards care and use of laboratory animals.

\section{References}

1. Ayinde O.C., Ogunnowo S., Ogedegbe R.A.: Influence of vitamin $\mathrm{C}$ and vitamin $\mathrm{E}$ on testicular zinc content and testicular toxicity in lead exposed albino rats. BMC Pharmacol Toxicol 2012, 13, 17. doi: 10.1186/2050-6511-13-17.

2. Bisogni S., Ferreira F.T., Amstalden Neto A., Chiarelli L.O., Ortiz V.: Influence of oxidative stress on inducing micturition dysfunction following chronic infravesical obstruction and the protective role of an antioxidant diet - association of in vivo and in vitro studies in rats. Int Braz J Urol 2012, 38, 552-560.

3. Bradford M.M.: A rapid and sensitive method for the quantitation of microgram quantities of protein utilizing the principle of protein-dye binding. Anal Biochem 1976, 72, $248-254$.
4. Chettri J.K., Deshmukh S., Holten-Andersen L., Jaafar R.M., Dalsgaard I., Buchmann K.: Comparative evaluation of administration methods for a vaccine protecting rainbow trout against Yersinia ruckeri O1 biotype 2 infections. Vet Immunol Immunopathol 2013, 154, 42-47.

5. Chettri J.K., Raida M.K., Kania P.W., Buchmann K.: Differential immune response of rainbow trout (Oncorhynchus mykiss) at early developmental stages (larvae and fry) against the bacterial pathogen Yersinia ruckeri. Dev Comp Immunol 2012, 36, 463-474.

6. Dubinina E.E., Burmistrov S.O., Khodov D.A., Porotov I.G.: Oxidative modification of human serum proteins. A method of determining it. Voprosy Meditsinskoĭ Khimii 1995, 41, 24-26.

7. Duracková Z.: Some current insights into oxidative stress. Physiol Res 2010, 59, 459-469.

8. Fernández L., Méndez J., Guijarro J.A.: Molecular virulence mechanisms of the fish pathogen Yersinia ruckeri. Vet Microbiol 2007, 125, 1-10.

9. Forman H.J., Maiorino M., Ursini F.: Signaling functions of reactive oxygen species. Biochemistry 2010, 49, 835-842.

10. Galaktionova L.P., Molchanov A.V., El'chaninova S.A., Varshavskiı̌ B.: Lipid peroxidation in patients with gastric and duodenal ulcers. Klin Labarat Diagn 1998, 6, 10-14.

11. García J.J., Reiter R.J., Guerrero J.M., Escames G., Yu B.P., Oh C.S., Muñoz-Hoyos A.: Melatonin prevents changes in microsomal membrane fluidity during induced lipid peroxidation. FEBS Lett 1997, 408, 297-300.

12. Gemma C., Vila J., Bachstetter A., Bickford P.C.: Oxidative stress and the aging brain: from theory to prevention. In: Brain Aging: Models, Methods, and Mechanisms. Chapter 15, edited by Riddle D.R., Boca Raton CRC Press, 2007.

13. Glatzle D., Vuilleumier J.P., Weber F., Decker K.: Glutathione reductase test with whole blood, a convenient procedure for the assessment of the riboflavin status in human. Experientia 1974, $30,665-667$.

14. Johnson K.A., Amend D.F.: Comparison of efficacy of several delivery methods using Yersinia ruckeri bacterin on rainbow trout, (Salmo gairdneri, Richardson). J Fish Dis 1983, 6, 331-336.

15. Kamyshnikov V.S.: Reference book on clinic and biochemical researches and laboratory diagnostics. MEDpress-inform, Moscow, 2004.

16. Klimp A.H., de Vries E.G.E., Scherphof G.L., Daemen T.: A potential role of macrophage activation in the treatment of cancer. Crit Rev Oncol Hematol 2002, 44, 143-161.

17. Koroliuk M.A., Ivanova L.I., Maĭorova I.G., Tokarev V.E.: A method of determining catalase activity. Laborotornoe Delo 1988, 1, 16-19.

18. Kostiuk, V.A., Potapovich, A.I., Kovaleva, Zh.V.: A simple and sensitive method of determination of superoxide dismutase activity based on the reaction of quercetin oxidation. Voprosy Meditsinskoĭ Khimii 1990, 36, 88-91.

19. Kurien B.T., Scofield R.H.: Autoimmunity and oxidatively modified autoantigens. Autoimmun Rev 2008, 7, 567-573.

20. Levine R.L., Garland D., Oliver C.N., Amic A., Climent I., Lenz A.G., Ahn B.W., Shaltiel S., Stadtman E.R.: Determination of carbonyl content in oxidatively modified proteins. Methods Enzymol 1990, 186, 464-478.

21. Makino N., Sasaki K., Hashida K., Sakakura Y.: A metabolic model describing the $\mathrm{H}_{2} \mathrm{O}_{2}$ elimination by mammalian cells including $\mathrm{H}_{2} \mathrm{O}_{2}$ permeation through cytoplasmic and peroxisomal membranes: comparison with experimental data. Biochim Biophys Acta 2004, 1673, 149-159.

22. Moin V.M.: A simple and specific method for determining glutathione peroxidase activity in erythrocytes. Labaratornoe Delo 1986, 12, 724-727.

23. Olesen N.J.: Detection of the antibody response in rainbow trout following immersion vaccination with Yersinia ruckeri bacterins by ELISA and passive immunization. J Appl Ichthyol 1991, 7, 36-43. 
24. Rahal A., Kumar A., Singh V., Yadav B., Tiwari R., Chakraborty S., Dhama K.: Oxidative stress, prooxidants, and antioxidants: the interplay. Biomed Res Int 2014, 761264. doi: $10.1155 / 2014 / 761264$.

25. Raida M.K., Buchmann K.: Bath vaccination of rainbow trout (Oncorhynchus mykiss Walbaum) against Yersinia ruckeri: effects of temperature on protection and gene expression. Vaccine 2008, 26, 1050-1062.

26. Ryckaert J., Bossier P., D'Herde K., Diez-Fraile A., Sorgeloos P., Haesebrouck F., Pasmans F.: Persistence of Yersinia ruckeri in trout macrophages. Fish Shellfish Immunol 2010, 29, 648-655.

27. Stadtman E.R., Levine R.L.: Free radical-mediated oxidation of free amino acids and amino acid residues in proteins. Amino Acids 2003, 25, 207-218.
28. Stevenson R.M.: Immunization with bacterial antigens: yersiniosis. Dev Biol Stand 1997, 90, 117-124.

29. Tobback E., Decostere A., Hermans K., Haesebrouck F., Chiers K.: Yersinia ruckeri infections in salmonid fish. J Fish Dis 2007, 30, 257-268.

30. Wiens G.D., Vallejo R.L.: Temporal and pathogen-load dependent changes in rainbow trout (Oncorhynchus mykiss) immune response traits following challenge with biotype 2 Yersinia ruckeri. Fish Shellfish Immunol 2010, 29, 639-647.

31. Yang H.C., Cheng M.L., Ho H.Y., Chiu D.T.: The microbicidal and cytoregulatory roles of NADPH oxidases. Microbes Infect 2011, 13, 109-120.

32. Zar J.H.: Biostatistical Analysis, Prentice Hall Inc., New Jersey, 1999. 